\title{
LUMINESCENCE METHOD - INSTRUMENT USED FOR DETECTION OF SURFACE CLEANLINESS
}

\author{
Jan Kudláček, Petr Chábera, Leon Šikulec
}

Preliminary notes

The process of surface treatment has a significant role in several industrial applications. Among the processes that most affect the quality of surface treatment are mainly the pre-treatment processes aimed at cleaning the processed surfaces. Degreasing of the treated surfaces has in this technological phase an important role. The article is devoted to quality control after surface pre-treatment. It deals with modern method for detecting grease-based surface contamination by the luminescence method. Impurities such as grease, oil and others have characteristic luminescence after illumination by UV light source. This principle can be used to determine the cleanliness of the part's surface thereby ensuring the quality of the observed surface. Surface cleanliness is a very important factor for the correct application of subsequent technological processes.

Keywords: degreasing; grease detection; oil film; Recognoil device; surface cleanliness

Metoda luminescencije - sredstvo za otkrivanje čistoće površine

Prethodno priopćenje Postupak površinske obrade ima značajnu ulogu u nekoliko industrijskih primjena. Među postupcima koji najviše utječu na kvalitetu površinske obrade su uglavnom oni koji prethode obradi i odnose se na čišćenje obrađivanih površina. Važnu ulogu u toj tehnološkoj fazi ima odmašćivanje obrađivanih površina. Članak se bavi kontrolom kvalitete nakon prethodne obrade površine. Opisuje suvremenu metodu za otkrivanje površine kontaminirane masnoćom primjenom metode luminescencije (svjetlucanja). Kod nečistoća kao što su masnoća, ulje i druge, pojavljuje se karakteristično svjetlucanje nakon izlaganja UV zrakama. Taj se princip može primijeniti za određivanje čistoće tog dijela površine i tako osigurati kvalitetu tretirane površine. Čistoća površine je vrlo važan čimbenik za ispravnu primjenu narednih tehnoloških postupaka.

Ključne riječi: čistoća površine; odmašćivanje; otkrivanje masnoće; Recognoil uređaj; uljani sloj

\section{Introduction}

In industrial practice various technological processes are often faced with errors in production caused by flaws or surface defects due to the greasing of the product's surface resulting in a system failure, and increased scrap rates in the production $[1,2]$. In particular, a grease has considerable importance on the properties of the final coating of products (functionality, appearance, and adhesion) being in particular important in production of bearings, forming tools, injection moulding tools [3] and other applications where high wear resistance is demanded. The reason for this is usually poor surface pretreatment aimed to degrease the part prior to the actual surface treatment process. Undefined grease on the part surface may influence not only the surface treatment (finishing) [4, 5, 6], but also a number of other technological processes such as welding $[7,8]$, soldering, and adhesive bonding. On the other hand, in some cases specific amount of grease on the surface is needed in order to protect it from corrosion $[9,10]$.

The ability to control the degree of part's surface cleanliness is mostly time-consuming. There is currently no effective, simple, and fast method dedicated to qualification and quantification of the surface cleanliness regarding to the presented amount of grease. The used precision methods are oriented towards controlled electrochemical cleaning [11] by oxygen radio-frequency plasma process and low-pressure plasma cleaning [12]. However, none of the used methods is dedicated to analysis of the surface pollution prior to the cleaning process. New possibilities of optimization of the cleaning processes with emphasis on surface degreasing are introduced by the Cleaning and Control $(\mathrm{C} \& \mathrm{C})$ concept used for the surface preparation. The "Cleaning and Control" [13] means the connection of degreasing process technology with its effective control. This creates a system where degreasing processes and their quality parameters are under on-line control of the operator.

To determine the degree of purity of the treated part numerous methods can be used [14] being divided into direct and indirect methods. Direct methods are used for immediate detection of grease on the analysed components. On the other hand indirect methods use detection options of impurities using the existing control solvent, which extracts the proportion of contaminants from the surface of the component to be measured and proportion of contamination is subsequently analysed from the solvent [13]. A direct method is more suitable for industrial use than an indirect method which is time consuming and demands transmitters, additional substances, reagents, and solvents on the observed surface being less practical for industrial application [8].

The article deals with a direct method based on grease luminescence and its detection. As it is clear from the method's name, the sample is being illuminated with a powerful UV source. Luminescence is a property natural to conjugated double bond hydrocarbons (alkenes), which creates the very basis of grease and oil substances [15]. Due to the grease ability of the luminescence on UV light the amount of impurities on the surface can be evaluated. The emerged visible light is detected by a super-sensitive visible light detector.

The surface is being uniformly irradiated with UV radiation while the light sensor simultaneously captures the grease luminescence. The acquisition of the data by the camera is followed by the picture evaluation resulting in creation of a luminescence distribution map - Fig. 1 . 


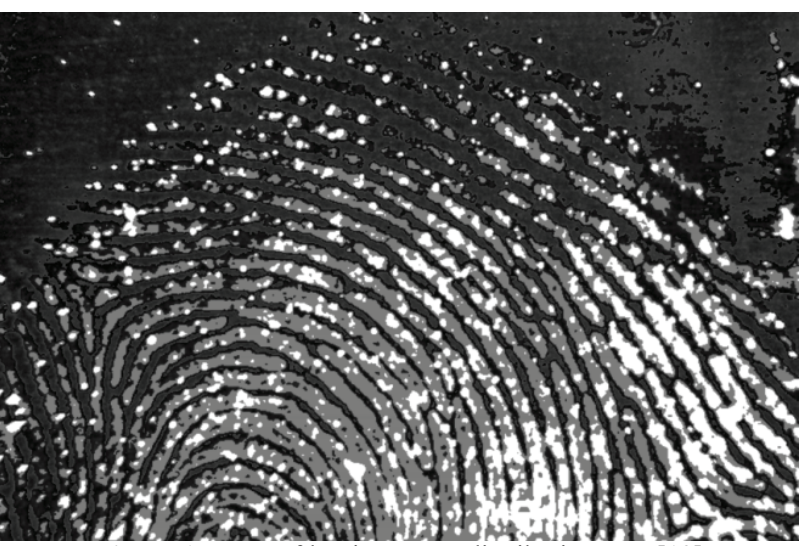

Figure 1 Image of luminescence distribution map [13]

\section{Mathematical model for detection}

The map of luminescence distribution still does not deliver useful information to the user except of the grease distribution on the surface layer of the observed part. The thickness of the oil in micrometres should be the direct result value. Therefore, post processing of the captured data is necessary. A procedure dedicated to the conversion of every single point on the luminescence distribution map to layer thickness is needed [16]. The bigger the luminescence value, the thicker is the grease or oil film. Thanks to a comparative method of direct weight measurement, a model of each type of oil/grease pollutant can be created.

The method is called sampling calibration and can be accomplished by applying a uniform and exact film of oil on the surface of the sample, whose weight increment is measured after film application [17]. Having prepared approximately ten samples of different film thicknesses, each sample is being illuminated and an average value of luminescence intensity is recorded. An appropriate mathematical model can be built by measured values interpolation, in most cases exhibiting exponential functionality.

The sampling calibration must be done separately for every type of base surface, since the results for different metal types may differ [16]. The influence of surface roughness is also considerable and needs to be evaluated separately.

\section{Sample preparation}

A very precisely electrolytically degreased small sheet of metal is irradiated with UV radiation and the resulting average luminescence intensity is recorded as the $I_{\mathrm{bmr}}$ value (i.e. base metal reference intensity). The sheet's weight is also recorded as $m_{\text {bmr }}$ value. After that, a certain amount of oil is dissolved in a solvent and applied to the surface of the object. After the solvent evaporation, the sample weight is measured precisely again to find out the $\mathrm{m}_{1}$ value, along with a new irradiation $I_{1}$ value. This process is then realized again several times with step-bystep increasing amount of oil dissolved in the solvent and the values $m_{i}$ and $I_{i}$ are recorded [18].

The thickness $T$ of the oil layer of density $\rho$ on the surface $S$ of the sample $i$ is:
$T_{i}=\frac{m_{i}-m_{\mathrm{bmr}}}{\rho S}$

The weight on surface ratio is:

$k_{i}=\frac{m_{i}-m_{\mathrm{bmr}}}{S}$

And the corresponding luminescence intensity $I_{i}$ is measured on every sample.

By inversing the chart and approximating the dependency, a direct equation for the thickness calculation will be:

$T=c \cdot I_{f}^{p}$,

$k=T \cdot \rho$

$I_{f}=I_{n}-I_{\mathrm{bmr}}$

In practice, with the knowledge of actual pollutant present on the known surface like it is the case after the deep drawing or turning process $[1,2]$, the detection process itself does not take more than 5 seconds to complete the evaluation of the surface pollution, thanks to Eq. (2) bringing the results of average film thickness in $\mu \mathrm{m}$ and average weight on surface in $\mathrm{g} / \mathrm{m}^{2}-$ Fig. 2 . The results of the mathematical model are presented in Figure 3 for one of the analysed oils.

\section{Static luminescence detection method}

This method is suitable for plain surfaces, where the detected surface's dimensions are approx. $20 \mathrm{~mm}$ by 15 $\mathrm{mm}$. As different types of oils may have very broad spectrum of luminescence capability, there must be a function present to control the detecting range. This is controlled by the time of exposure. Some oils show very high rate of luminescence (for example 0,6 unit at exposure of $100 \mathrm{~ms}$ ), while other types show only very slight luminescence (for example 0,2 unit at $2000 \mathrm{~ms}$ of exposure time). The luminescence capabilities are very diverse. This method is evidently one of the fastest and easiest and can be used as a random checking procedure in the production. Also this method can be used to localize fingerprint traces as presented in Fig. 1.

\section{Continuous luminescence detection method for 3D and / or moving object scanning}

Recently, a new technique has been developed, focusing on grease detection ability on non-planar 3D objects. Since the detector captures visible light and it is not possible to entirely shield the detector and the object from the surrounding environment light, it was almost impossible to scan 3D objects under normal conditions using UV irradiation and luminescence analysis.

A new method has been developed for sequential ambient light elimination. The surface is being illuminated by UV radiation in pulses of several times per second, while the detector captures continuously also the inter-UV-frames (Fig. 5, Frame ${ }_{\mathrm{A}}$ ), without UV radiation present. Knowing the inter-frame's ambient light 
distribution map, the applied software can easily eliminate its influence as it is evident from the sequence diagram in Fig. 5.

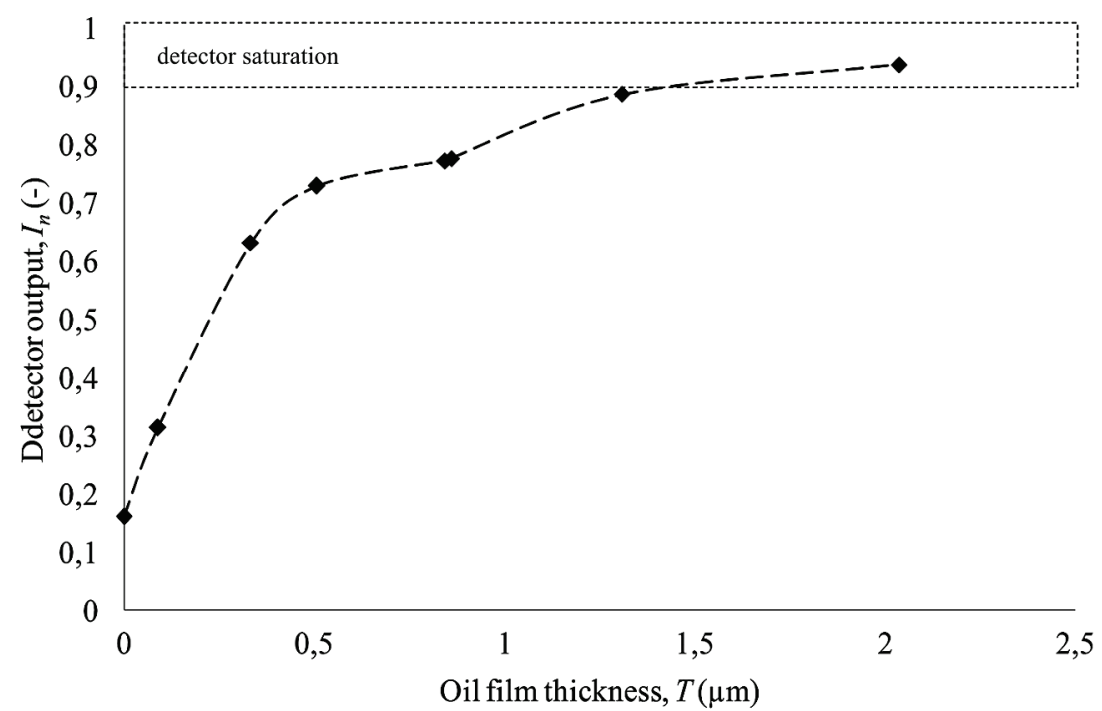

Figure 2 Directly weight-measured layer thicknesses vs. relative detector output

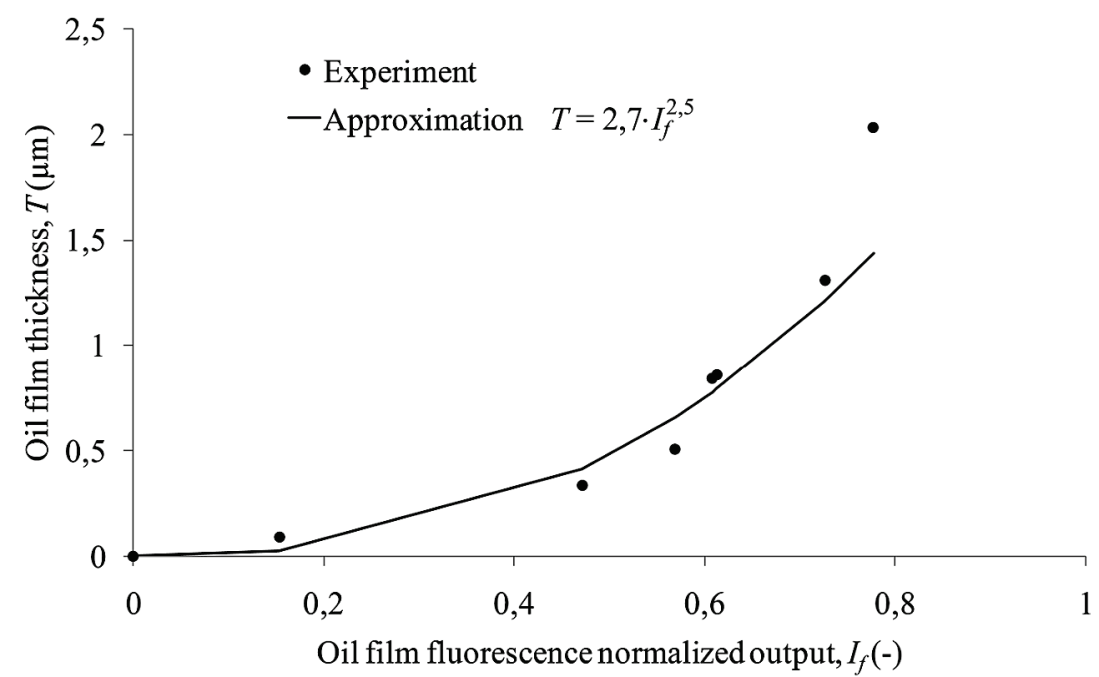

Figure 3 Building the oil mathematical model

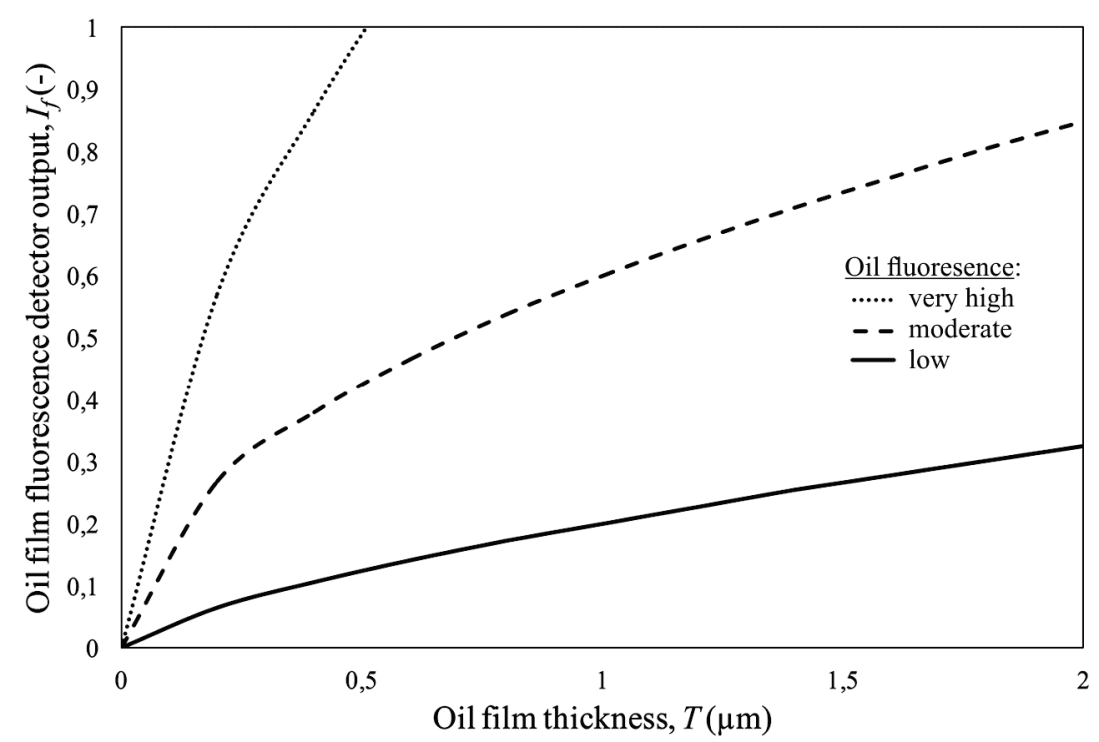

Figure 4 Divergent luminescence capabilities of various oils 


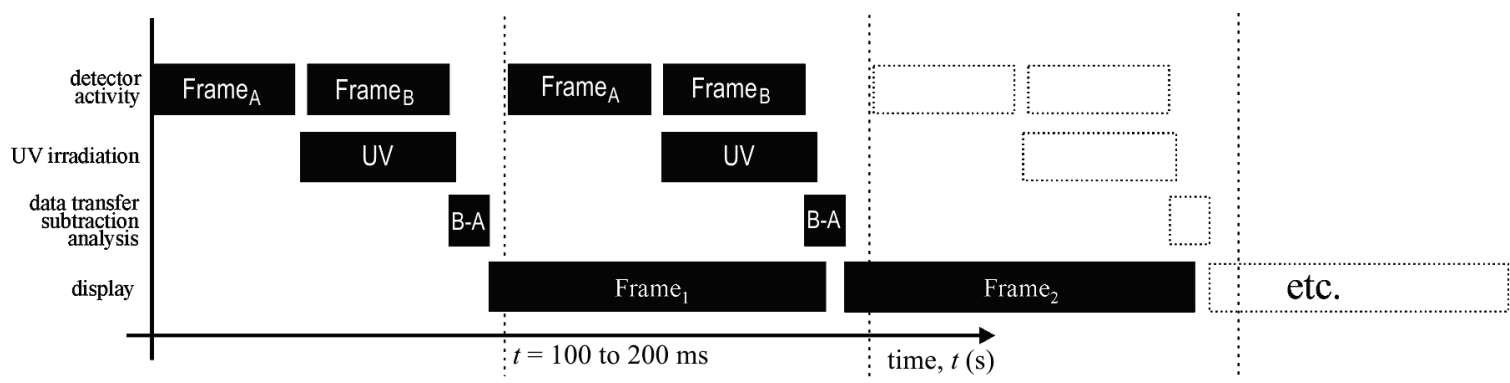

Figure 5 Ambient light influence negation

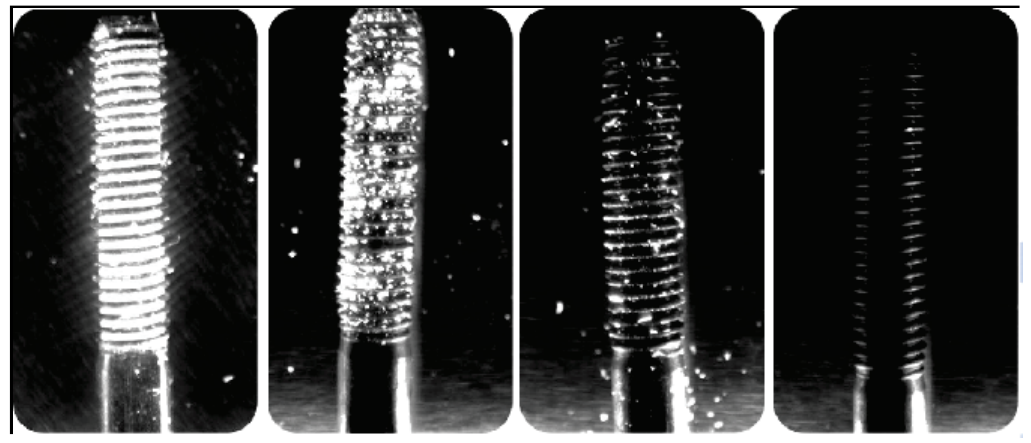

Figure 6 Control of cleanliness of the screw during the cleaning process using luminescence methods

This detection can be used for example for spot checks surfaces focusing on oily, but also dust impurities in crack detection. It can be permanently installed on a production line. It serves as a good solution for conducting random inspection of bigger and non-planar objects. Last but not least, the method can be used in relation to any moving object, such as sheets of metal on the conveyor belt, etc. Continuous detection method is universal and can be used directly for the operation because it requires no special lighting conditions. When you press and hold the shutter of the acquisition device an uninterrupted image sequence is obtained and manual detector can scan the object. Some of such scans can be obtained from the literature and on the internet [19] for the evaluation purposes of the presented method. An example of part cleaning evaluation on a case of screw cleaning is presented in Fig. 6. The irradiation by UV light and evaluation of the presented illumination method after particular cleaning period is evident from the left to the right - Fig. 6 .

\section{Conclusion}

In the paper an overview of extensive research work is presented resulting in industrial application of grease recognition on the part surfaces. An extensive research in oil detection capabilities was performed and a direct grease evaluation device called Recognoil was developed [20]. The results of this research work should finally bring an easy and exact method of surface oil detection, helping many other companies in the surface treatment branch to achieve higher quality of the treatments and decrease the production costs. Use of the Recognoil device can be applied mainly in quality control sector in industrial degreasing applications where high demands are placed on the surface cleanliness. This device can also be used for detection of defects in welding and control of layers deposited preservatives. A special provision is detection of fingerprint stop and purity detection in health care or anywhere else where it can be used to detect the principle of luminescence substances.

To ensure the necessary quality finishes of machine parts it is necessary to ensure perfect cleanliness of the surface. The most important operations in the process of finishes are degreasing operations. Surface cleanliness can be achieved only by quality degreasing technology performed with proper technological parameters. Selecting a suitable degreasing agent must be based on the conditions and possibilities of the workplace and the use of appropriate degreasing technology. An important factor in the analysis and the degree of surface cleanliness is achievable. To check the surface cleanliness appropriate use of Recognoil detection device is essential being able to guarantee control of degreasing parts in real time. This advanced detection method, working on the principle of luminescence allows to control the technological process of scouring and to select optimal parameters of degreasing tanks resulting in the extension of their service life, reducing time of degreasing operations and thereby minimizing production costs.

\section{Acknowledgements}

This article was written in cooperation with TechTest, s.r.o. and supported by the project SGS13/187/OHK2/3T/12 "Research and Development of Advanced Manufacturing Technologies," and an international exchange program CEEPUS HR -108.

\section{References}

[1] Kršulja, M.; Car, Z.; Radelja, H. Behaviour of X5 CrNiMo 17-12-2 Material during Deep Drawing Process. // Metalurgija. 51, 2(2012), pp. 203-206.

[2] Car, Z.;Barišić, B.;Ikonić, M. GA Based CNC Turning Center Exploitation Process Parameters Optimization. // Metalurgija. 48, 1(2009), pp. 47-50. 
[3] Brnic, J.; Canadija, M.; Turkalj, G. et al. Tool Material Behavior at Elevated Temperatures. // Materials and Manufacturing Processes. 24, 7-8(2009), pp. 758-762.

[4] Kaftanoğlu, B.; Dökmetaş, N. Performance of boron nitride coated tools and dies. // Advances in Production Engineering \& Management. 8, 3(2013), pp. 177-184. DOI: 10.14743/apem2013.3.165

[5] Herakovič, N.; Bevk, T. Analysis of the material and the actuator influence on the characteristics of a pneumatic valve // Materiali in tehnologije. 44, 1(2010), pp. 37-40.

[6] Cinca, N.; Lima, C. R. C.; Guilemany, J. M. An overview of intermetallics research and application: Status of thermal spray coatings. // Journal of Materials Research and Technology. 2, 1(2013), pp. 75-86. DOl: 10.1016/j.jmrt.2013.03.013

[7] Herakovič, N.; Šimic, M.; Trdič, F.; Skvarč, J. A machinevision system for automated quality control of welded rings. // Machine visions and applications. 22, 6(2011), pp. 967-981, DOI: 10.1007/s00138-010-0293-9

[8] Klobčar, D.; Tušek, J.; Skumavc, A.; Smolej, A. Parametric study of friction stir spot welding of aluminium alloy 5754 . // Metalurgija. 53, 1(2014), pp. 21-24.

[9] Plančak, M.; Car, Z.; Kršulja, M.; Vilotić, D.; Kačmarcik, I.; Movrin, D. Possibilities to Measure Contact Friction in Bulk Metal Forming. // Tehnicki Vjesnik-Technical Gazette. 19, 4(2012), pp. 727-734.

[10] Plančak, M.; Movrin, D.; Vilotić, D.; Car, Z.; Ivanišević, A.; Kačmarcik, I. An analysis of non-axisymmetric backward extrusion. // Tehnicki Vjesnik-Technical Gazette. 19, 4(2012), pp. 953-957

[11] Korzec, D.; Rapp, J.; Theirich, D.; Engemann, J. Cleaning of Metal Parts in Oxygen Radio-Frequency Plasma Process Study. // Journal of Vacuum Science \& Technology A - Vacuum Surfaces and Films. 12, 2(1994), pp. 369-378. DOI: 10.1116/1.579249

[12] Petasch, W.; Kegel, B.; Schmid, H.; Lendenmann, K.; Keller, H. U. Low-pressure plasma cleaning: a process for precision cleaning applications. // Surface and Coatings Technology. 97, 1-3(1997), pp. 176-181.

[13] Pacák, L.; Kudláček, J. The Calibration of a Device Used for the Detection of Surface Cleanliness. // Proceedings of CO-MAT-TECH 2005. Bratislava: Vydavatel'stvo STU, 2005, pp. 882-889.

[14] Kudláček, J.; Kreibich, V. Optimalization of Cleaning Process. // Proceedings of CO-MAT-TECH 2004. Bratislava: Vydavatel'stvo STU, 2004, pp. 707-713.

[15] Kudláček, J.; Chábera, P.; Barisic, B. New possibilities of degreasing process evaluation. // Proceedings of International Conference on Innovative Technologies INTECH 2010, Jaroměř: Centrum pro povrchovéúpravy, 2010, pp. 624-627.

[16] Kudláček, J.; Chábera, P.; Pepelnjak, T.; Car, Z. Mathematical modelling of surface grease deposits. // Proceedings of International Conference on Innovative Technologies IN-TECH 2012. Rijeka: Faculty of Engineering University of Rijeka, 2012, pp. 335-338.

[17] Kuznetsov, A. P.; Božek, P. Aplikácia matematického vyjadrenia spol'ahlivosti technických systémov. Trnava, Tripsoft, 2009, $73 \mathrm{p}$.

[18] Plankovskiy, S.; Trifinov, O.; Shypul, O.; Kozlov, V.; Szalay, T. Simulation of removing mechanism of free particles from surface by detonable gaseous mixtures. // Manufacturing 2012. Budapest, Hungary, 2012, pp. 1-8.

[19] http://www.youtube.com/watch? $=\mathrm{vGv} 4 \mathrm{c} 4 \mathrm{Z} 7 \mathrm{xTw}$ (13.2.2014)

[20] http://www.techtest.eu/TECHDATA2013-ENG.pdf (13.02.2014)

\section{Authors' addresses}

Jan Kudláček, Ing. Ph.D.

CTU in Prague, Faculty of Mechanical Engineering Technická 4, 16607 Prague, Czech Republic E-mail: Jan.Kudlacek@ffs.cvut.cz

\section{Petr Chábera, Ing.}

CTU in Prague, Faculty of Mechanical Engineering Technická 4, 16607 Prague, Czech Republic E-mail: Petr.chabera@fs.cvut.cz

\section{Leon Šikulec}

University of Rijeka, Faculty of Engineering

Vukovarska 58, 51000 Rijeka, Croatia

E-mail: 1sikulec@riteh.hr 